\title{
Yield Attributes and Yield of Urdbean as Influenced by Foliar Application of Salicylic Acid under Rainfed Condition
}

\author{
Deepak Kumar Rawat ${ }^{1 *}$, M.A. Khan ${ }^{1}$, Nirmal Kumar ${ }^{1}$, Amit Kumar ${ }^{1}$ and Raj Kumar ${ }^{2}$ \\ ${ }^{1}$ Department of Plant Physiology, C.S.A. University of Agriculture and Technology \\ Kanpur-208002, India \\ ${ }^{2}$ Department of Soil conservation and Water Management, C.S.A. University of Agriculture \\ and Technology Kanpur-208002, India
}

*Corresponding author

\section{A B S T R A C T}

The experiment was conducted in the department of Plant Physiology C S Azad University of Agriculture \& Technology. Kanpur in field during

Keywords

Foliar application,

salicylic acid, Day after

Sowing, Parts per million,

Treatment

Article Info

Accepted:

12 July 2019

Available Online:

10 August 2019 kharif session 2017 adopted Randomized Block Design with 10 treatments and Azad - 3 variety including control and each treatment was replicated three times with three levels of salicylic acid i.e. 50, 100 and $150 \mathrm{ppm}$ at the time of 20 DAS, 40 DAS and 60 DAS which was given through foliar application. Results maximum increase in yield and yield attributes viz., number of pods/plant, dry weight/plant, seed yield/plant, 100 seed weight (g), seed yield $\mathrm{q} / \mathrm{ha}$ and harvest index $(\%)$ was recorded under the treatment of salicylic acid @ 150 ppm followed by 100 and 50 ppm of salicylic acid over control. Thus, in general it may be concluded that the foliar application of salicylic acid @ 150 ppm was found optimum concentration in enhancing yield of Black gram over rest of treatment under rain fed conditions.

\section{Introduction}

Blackgram is one of the most highly prized pulse crop, cultivated in almost all parts of India. It has inevitably marked itself as the most popular pulse and can be most appropriately referred to as the "king of the pulses" due to its mouth watering taste and numerous other nutritional qualities. Whether it be the very special "Dal makhni" of Punjab or the "Vada Sambhar" of South India, the taste rules the hearts of one and all alike. Indian immigrants have popularized the taste worldwide as well.

In Japan, the health conscious people eat these seeds by soaking them in water overnight and then serving them as fresh bean sprout salad which is highly nutritious. Blackgram is perfect combination of all nutrients, which 
includes proteins (25-26\%), carbohydrates (60\%), fat (1.5\%), minerals, amino acids and vitamins. The decreasing per capita availability of pulses from 1951in $60.7 \mathrm{~g}$ and 2000 in $35.9 \mathrm{~g}$ of great concern in the India contest where most of the peoples are vegetarian. An average adult man would require bog and adult woman $50 \mathrm{~g}$ of protein per day.

Black gram also known as urd, mash in India. In India total black gram production was estimated 14.76 million tonnes from 23.63 million hectare area with productivity of 642 $\mathrm{kg} / \mathrm{ha}$. Grain legumes occupy a unique position in Indian agriculture as they provide vegetable protein for human diet, pulse are also important in our agriculture system because of their nitrogen fixing ability about $40 \%$ of the total nitrogen in the world in added by leguminous plant. They can also suit to dry farming condition because of their ability to trap moisture from deep layers of the soil by virtue of their deep penetrating root system.

In India, it is the fourth important pulse crop after chickpea and pigeon pea, green gram is cultivated in state of Rajasthan, Madhya Pradesh, Punjab, Haryana, U.P., Maharashtra, Karnataka, Andhra Pradesh and Tamil Nadu. In Uttar Pradesh, it is being cultivated in an area of 3.91 lakhs hectare with 1.72 lakhs tonnes production Anonymous (2014).

The main reason of low productivity of the green gram is cultivation on marginal and submarginal lands with no use of recommended dose of fertilizers. Flowering is important parameter that is directly related to yield and productivity of plants. Salicylic acid has been reported to in duce flowering in a number of plants. Different plant species including ornamental plant Sinningia speciosa flowered much earlier as compared to the untreated control, when they received an exogenous foliar spray of salicylic acid.

\section{Materials and Methods}

The experiment was conducted geographically, Kanpur is situated in the central part of U.P. and subtropical tract of North India between latitude ranging from $25^{\circ}$ $56^{\prime}$ to $28^{\circ} 58^{\prime}$ North and longitude $79^{\circ} 31^{\prime}$ to $80^{\circ} 34^{\prime}$ 'East and is located on an elevation of about 125.9 meters above mean sea level in gangetic plain. The seasonal rainfall of about $816 \mathrm{~mm}$ received mostly from II $^{\text {nd }}$ Fortnight of June or first Fortnight of July to mid-October with a few showers in winter season.

The experiment was conducted in randomized block design with 3 replications. Seed of Azad-3 variety were used in this experiment.

Pure seeds of variety were obtained from the Economic botanist (Legume section) of this University.

\section{Treatment combination and symbols}

Control - $\mathrm{T}_{1}$

Folair application of salicylic acid @ 50 ppm (20 DAS) - $\mathrm{T}_{2}$

Foliar application of salicylic acid @ 50 ppm (40 DAS) - $\mathrm{T}_{3}$

Foliar application of salicylic acid @ 50 ppm (60 DAS) - $\mathrm{T}_{4}$

Folair application of salicylic acid @ 100 ppm (20 DAS) - $\mathrm{T}_{5}$

Foliar application of salicylic acid @100 ppm (40 DAS) - $\mathrm{T}_{6}$

Foliar application of salicylic acid @ 100 ppm (60 DAS) - $\mathrm{T}_{7}$

Folair application of salicylic acid @ 150 ppm (20 DAS) - $\mathrm{T}_{8}$ 
Foliar application of salicylic acid @ 150 ppm (40 DAS) - $\mathrm{T}_{9}$

Foliar application of salicylic acid @ 150 ppm (60 DAS) - $\mathrm{T}_{10}$

\section{Application of fertilizers}

The experimental field was fertilized with recommended dose of NPK /ha @ $20 \mathrm{Kg} \mathrm{N}$, $40 \mathrm{Kg} \mathrm{P}_{2} \mathrm{O}_{5}$ and $20 \mathrm{Kg} \mathrm{K}_{2} \mathrm{O}$. Basal manuring experimental field was ploughed once with a soil turning plough and two ploughings with desi plough. Finally, it was planked to give a uniform level. The sowing was done in plot with plant to plant $40 \mathrm{~cm}$, row to row $10 \mathrm{~cm}$ and depth 5-8 $\mathrm{cm}$ below. All the data analysis related to yield and yield contributing characters as well as chemical analysis were statistically analyzed by the methods suggested by Fisher (1935). Plant sampling method randomly three plants were taken out from each urdbean variety at different growth stages, and the data on different traits were recorded on these plants.

\section{Results and Discussion}

\section{Effect of salicylic acid on yield attributes of urdbean}

Above observations were recorded at different stages as 35 DAS, 70 DAS, and harvesting and sprayed of the salicylic acid at 20 DAS 40 DAS and 60 DAS on the foliar application. All level of foliar application of salicylic acid better response in yield attributes viz. that number of pods, 100 seed economic yield, biological yield, harvest index and yield varied significantly due to foliar application of salicylic acid treatment and their significantly.

Maximum value of all traits obtained in $\mathrm{T}_{10}$ under salicylic acid (150 ppm) comparison of all other treatments as well as control. Yield and yield attributes were reported significant results in salicylic acid $\mathrm{T}_{10}, \mathrm{~T}_{9}, \mathrm{~T}_{8}$ in higher comparison to salicylic acid $100 \mathrm{ppm} \mathrm{T}_{7}, \mathrm{~T}_{6}$, $\mathrm{T}_{5}$, and salicylic acid $50 \mathrm{ppm} \mathrm{T}_{4}, \mathrm{~T}_{3}, \mathrm{~T}_{2}$ and all treatments give significant results than control $\left(\mathrm{T}_{1}\right)$. Among the different levels of salicylic acid, application @ 150 ppm was found significantly better and positively influenced all traits under rain fed conditions. Coefficient variance revealed that yield possessed significantly positive yield attributes and yields indicates involvement of these traits in yield formation process under stress environment condition.

\section{Number of pods/plant}

A perusal of data on number of pods as presented in Table 1 and Figure 1 showed that different levels of treatments significantly increased the number of pods over control at harvest stage. Maximum number of pods was recorded in the treatment of salicylic acid 150 ppm 60 DAS closely followed by salicylic acid -150 ppm. 40 DAS and over controls. It was inferred that application of salicylic acid similar result was also reported Sujatha (2001), Amin et al., (2009) and Ali and Mahmoud (2013) number of pods per plant components of urdgbean.

\section{Dry weight of pods}

Data as depicted in Table 1 and Figure 1 showed that foliar application of salicylic acid @ $150 \mathrm{ppm}$ influenced dry weight of pods at maturity stages of crop growth. Significantly higher dry weight was observed in $\left(\mathrm{T}_{10}\right) 8.99$ each other treatment. Similar result was also reported Amin et al., (2009), Ali and Mahmoud (2013) and Sathiyamurthy et al., (2017) number of pods per plant components of urdgbean.

\section{Seed yield per plant}

The data presented in Table 2 and Figure 2 revealed that the seed yield per plant significantly increased. Maximum seed yield 
per plant was recorded by the treatment $\left(\mathrm{T}_{10}\right)$ and other all treatment over control. The application of salicylic acid conferred an increase in leaf area. An improvement in leaf area following SA application in plants grown under saline conditions was also reported by Sathiyamurthy et al., (2017).

Table.1 Effect of different doses of salicylic acid on number of pod and dry weight of pod per plant at maturity of black gram during 2017

\begin{tabular}{|c|c|c|}
\hline Treatment & No. of pod at maturity & Dry weight of pod at maturity \\
\hline Control - $\mathbf{T}_{1}$ & 21.00 & 5.00 \\
\hline FA of SA $50 \mathrm{ppm} 20$ DAS - $\mathrm{T}_{2}$ & 23.66 & 5.61 \\
\hline FA of SA $50 \mathrm{ppm} 40 \mathrm{DAS}-\mathrm{T}_{3}$ & 25.00 & 5.86 \\
\hline FA of SA $50 \mathrm{ppm} 60 \mathrm{DAS}-\mathrm{T}_{4}$ & 28.00 & 6.19 \\
\hline FA of SA $100 p p m 20$ DAS $-T_{5}$ & 30.33 & 6.36 \\
\hline FA of SA $100 p p m 40$ DAS -T & 34.66 & 6.93 \\
\hline FA of SA $100 p p m 60$ DAS -T & 37.66 & 7.32 \\
\hline FA of SA $150 p p m 20$ DAS -T & 41.33 & 7.90 \\
\hline FA of SA $150 \mathrm{ppm} 40$ DAS -T, & 44.33 & 8.39 \\
\hline FA of SA $150 p p m 60$ DAS - $T_{10}$ & 46.00 & 8.99 \\
\hline CD & 2.50 & 0.60 \\
\hline SE(D) & 1.18 & 0.28 \\
\hline CV & 4.36 & 5.08 \\
\hline
\end{tabular}

Note- FA - Foliar application, SA - salicylic acid, DAS - Day after Sowing, PPM - Parts per million and T Treatment symbols

Table.2 Effect of different doses of salicylic acid on seed yield per plant and test weight (g) per plant at maturity of black gram during 2017

\begin{tabular}{|c|c|c|}
\hline Treatment & Seed yield per plant & Test weight (g) \\
\hline Control - $\mathbf{T}_{1}$ & 2.44 & 3.24 \\
\hline FA of SA $50 \mathrm{ppm} 20$ DAS - $\mathrm{T}_{2}$ & 2.62 & 3.32 \\
\hline FA of SA $50 \mathrm{ppm} 40$ DAS - $\mathrm{T}_{3}$ & 2.98 & 3.52 \\
\hline FA of SA $50 \mathrm{ppm} 60 \mathrm{DAS}-\mathrm{T}_{4}$ & 3.23 & 3.59 \\
\hline FA of SA $100 \mathrm{ppm} 20 \mathrm{DAS}-\mathrm{T}_{5}$ & 3.59 & 3.70 \\
\hline FA of SA $100 \mathrm{ppm} 40 \mathrm{DAS}-\mathrm{T}_{6}$ & 3.97 & 3.76 \\
\hline FA of SA $100 \mathrm{ppm} 60 \mathrm{DAS}-\mathrm{T}_{7}$ & 4.52 & 3.94 \\
\hline FA of SA $150 \mathrm{ppm} 20$ DAS - $\mathrm{T}_{8}$ & 5.49 & 4.03 \\
\hline FA of SA 150 ppm 40 DAS -T, & 6.06 & 4.27 \\
\hline FA of SA $150 p p m 60$ DAS $-T_{10}$ & 6.66 & 4.41 \\
\hline CD & 0.46 & 0.14 \\
\hline SE(D) & 0.28 & 0.06 \\
\hline CV & 6.40 & 2.20 \\
\hline
\end{tabular}

Note- FA - Foliar application, SA - salicylic acid, DAS - Day after Sowing, PPM - Parts per million and T Treatment symbols 
Table.3 Effect of different doses of salicylic acid on yield q/ha and harvest index (\%) after maturity of black gram during 2017

\begin{tabular}{|c|c|c|c|}
\hline Treatment & $\begin{array}{l}\text { Biological yield } \\
\text { q/ha }\end{array}$ & $\begin{array}{l}\text { Seed yield } \\
\text { q/ha }\end{array}$ & $\begin{array}{c}\text { Harvest index } \\
(\%)\end{array}$ \\
\hline Control - $T_{1}$ & 12.35 & 8.20 & 18.21 \\
\hline FA of SA $50 \mathrm{ppm} 20 \mathrm{DAS}-\mathrm{T}_{2}$ & 13.72 & 8.40 & 19.08 \\
\hline FA of SA $50 \mathrm{ppm} 40 \mathrm{DAS}-\mathrm{T}_{3}$ & 14.76 & 8.90 & 20.18 \\
\hline FA of SA $50 \mathrm{ppm} 60 \mathrm{DAS}-\mathrm{T}_{4}$ & 15.56 & 9.30 & 20.75 \\
\hline FA of SA $100 p p m 20$ DAS -T 5 & 16.29 & 9.45 & 22.02 \\
\hline FA of SA $100 \mathrm{ppm} 40$ DAS -T 6 & 17.50 & 9.85 & 22.68 \\
\hline FA of SA $100 \mathrm{ppm} 60 \mathrm{DAS}-\mathrm{T}_{7}$ & 18.47 & 9.95 & 24.46 \\
\hline FA of SA $150 \mathrm{ppm} 20$ DAS -T 8 & 19.76 & 10.10 & 27.77 \\
\hline FA of SA 150 ppm 40 DAS -T, & 20.86 & 10.20 & 29.04 \\
\hline FA of SA 150 ppm 60 DAS -T 10 & 21.97 & 10.35 & 30.30 \\
\hline CD & 1.98 & 0.014 & 0.14 \\
\hline SE(D) & 0.93 & 0.007 & 0.06 \\
\hline CV & 6.68 & 0.088 & 0.35 \\
\hline
\end{tabular}

Note- FA - Foliar application, SA - salicylic acid, DAS - Day after sowing, PPM - Parts per million and T Treatment symbols

Fig.1: Effect of different doses of salicylic acid on number of pod and dry weight of pod per plant at maturity of black gram during 2017

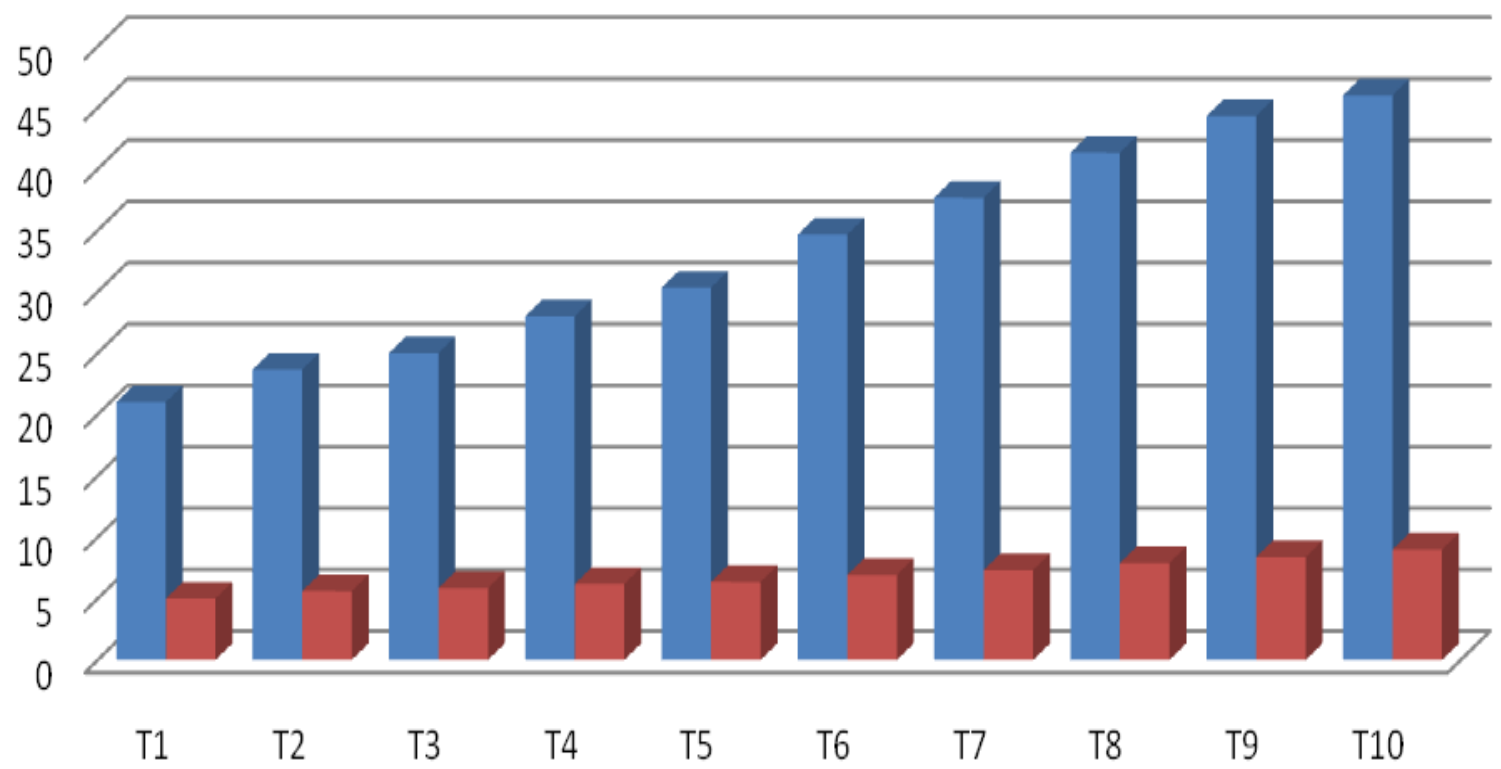

No. of pod at maturity Dry weight of pod at maturity 


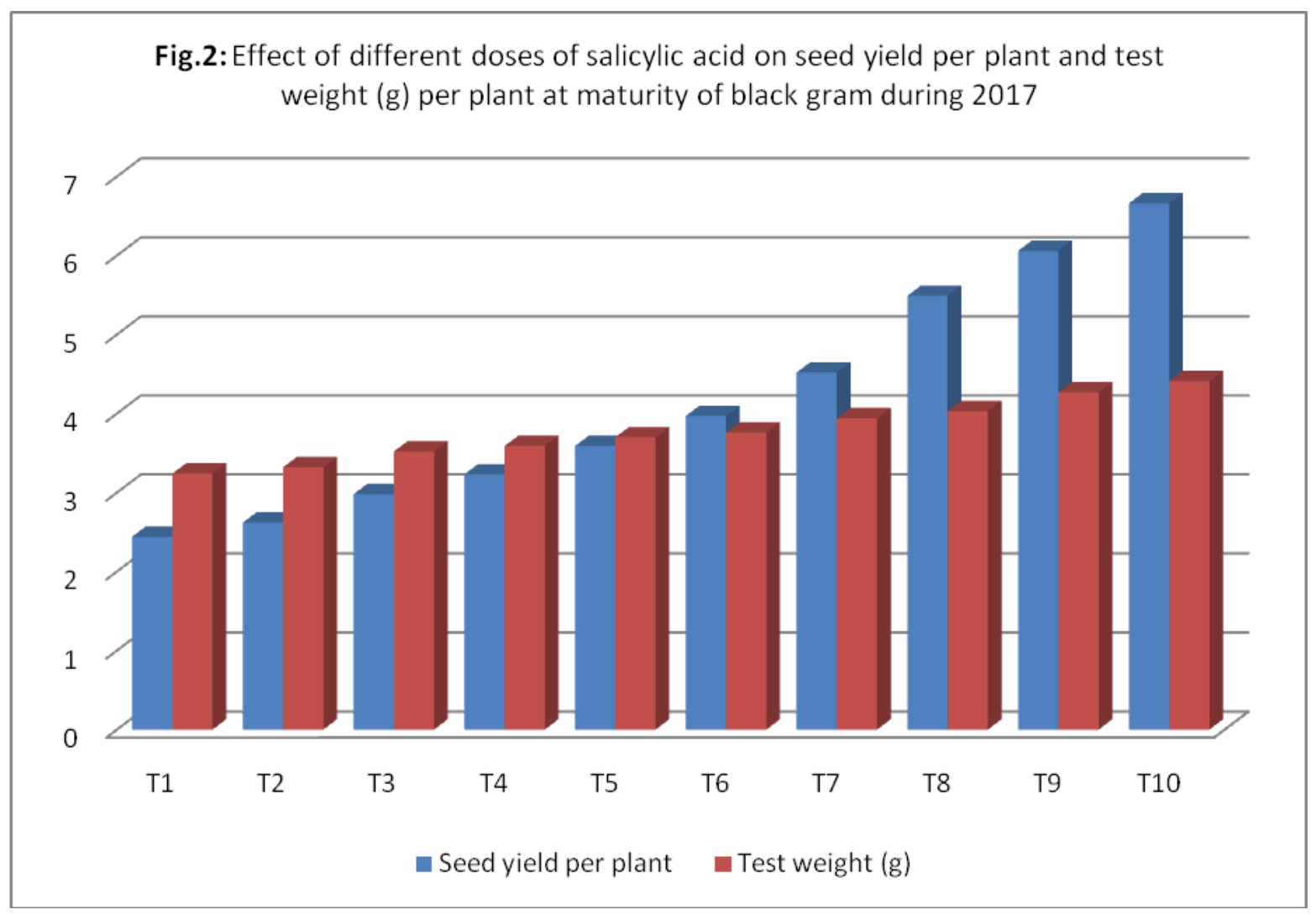

Fig.3: Effect of different doses of salicylic acid on yield q/ha and harvest index (\%) after maturity of black gram during 2017

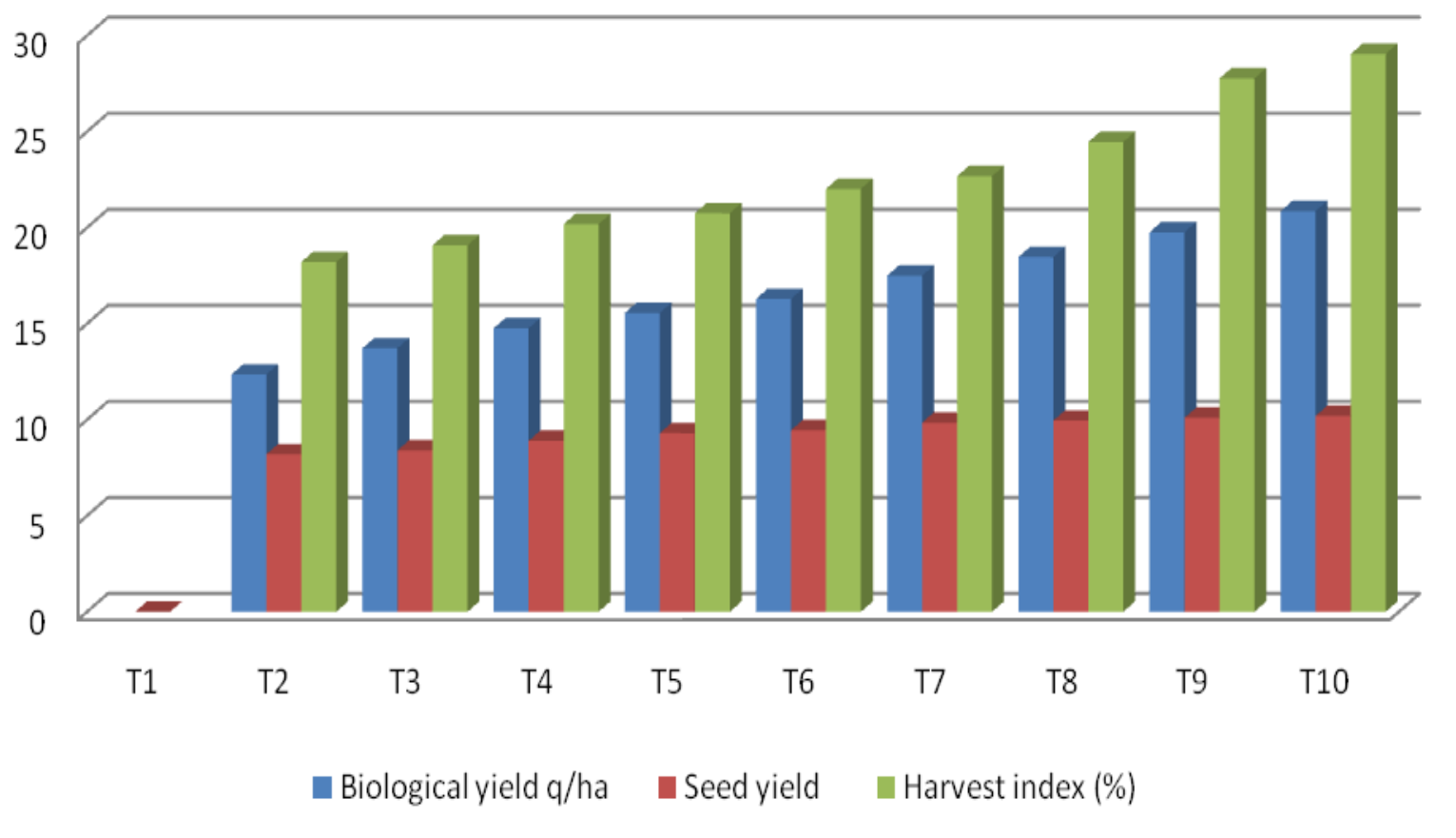




\section{Seed test weight (g)}

Different foliar application of salicylic acid treatments significantly increased the seed index weight over the control. The maximum 100 seed weight was obtained treatment $\left(\mathrm{T}_{10}\right)$ wt. 4.41g followed by all other treatment. Similar result was also reported Sujatha (2001), Ali and Mahmoud (2013), Sathiyamurthy et al., (2017) number of pods per plant components of urdgbean crops.

\section{Effect of salicylic acid on yields and harvest index of urdbean}

The seed yield per unit area is an important scale for agronomic assessment of the crop. The suitability of the treatment is best judged by their efficiency to produce higher yield. Yield of any crop is the ultimate result of interaction of the biotic and environment factors. The superiority or inferiority of any treatment could be judged by magnitude of changes brought in the productivity.

\section{Biological yield q/ha}

A perusal of data on harvest index as presented in Table 3 and Figure 3 the data recorded on biological yield in $\mathrm{kg} / \mathrm{ha}$ was converted into seed yield in quintals/ha the data revealed that all the foliar application of salicylic acid gave significant response on seed yield over control treatments $\left(\mathrm{T}_{1}\right)$. The maximum grain yield $(21.97 \mathrm{q} / \mathrm{ha})$ in treatment $\left(\mathrm{T}_{10}\right)$ was recorded with the foliar application of salicylic acid @ $150 \mathrm{ppm}$ at 60 DAS. It was found significantly superior than all the other treatments the minimum biological yield (12.35 q/ha) was recorded in control treatment $\left(\mathrm{T}_{1}\right)$. Similar result was also reported Ali and Mahmoud (2013) and Sathiyamurthy et al., (2017) seed yield and yield components of urdgbean.

\section{Seed yield $q / h a$}

A perusal of data on harvest index as presented in Table 3 and Figure 3 the data recorded on seed yield in $\mathrm{kg} / \mathrm{ha}$ were converted into seed yield in quintals/ha the data revealed that all the foliar application of salicylic acid gave significant response on seed yield over control treatments $\left(\mathrm{T}_{1}\right)$. The maximum grain yield $(10.35 \mathrm{q} / \mathrm{ha})$ in treatment $\left(\mathrm{T}_{10}\right)$ was recorded with the foliar application of salicylic acid @ $150 \mathrm{ppm}$ at $60 \mathrm{DAS}$. It was found significantly superior than all the other treatments the minimum seed yield $(8.20 \mathrm{q} / \mathrm{ha})$ was recorded in control treatment $\left(\mathrm{T}_{1}\right)$. Foliar application of different treatment of salicylic acid had significant variation in the biological and seed yield of black gram. Among the treatments, foliar application of salicylic acid $150 \mathrm{ppm}$ at 60 DAS recorded significantly higher both yield. Similar result was also reported Ali and Mahmoud (2013) and Sathiyamurthy et al., (2017) seed yield and yield components of urdgbean.

\section{Harvest index}

A perusal of data on harvest index as presented in Table 3 and Figure 2 showed that it varied significantly due to foliar application of salicylic acid treatment. Harvest index increased significantly in treatment $\left(\mathrm{T}_{10}\right)$ over each other treatment. Further, it also appears that application of salicylic acid @ 150 ppm at 60 DAS resulted in significantly higher $30.30 \%$ over control $18.21 \%$ over rest of treatments. Harvest index as depicted in us that it varied significantly due to variation, treatment of foliar application of salicylic acid @ 150 ppm recorded high yield and harvest index from the result it appears application of salicylic acid @ 150 ppm had positive effect on yield and harvest index. A similar result was also established by Ali and Mahmoud (2013) and Sathiyamurthy et al., (2017).

Above observations were recorded at different stages as 35 DAS, 70 DAS, and harvesting and sprayed of the salicylic acid at 20 DAS 40 DAS and 60 DAS on the foliar application. All level of foliar application of salicylic acid better response in yield attributes viz. that number of pods, 100 seed economic yield, biological yield, harvest index and yield varied significantly due 
to foliar application of salicylic acid treatment and their significantly. The results obviously suggest and it may be concluded that foliar application of salicylic acid on urdbean variety Azad - 3 significantly change in plant morphology, improvement in vegetative and reproductive growth to enable them for higher yield build up and the affects initiated once were carried over through the life cycle of plant. These substances judiciously work out can be employed successfully for yield maximization of urdbean.

\section{Acknowledgement}

I feel golden opportunity with great pleasure in acknowledging my profound sense of veneration and gratitude to my major advisor and Chairman, Dr. M.A. Khan. The authors are thankful to the Department for providing the required research facilities. I gratefully express my deep sense gratifies to my respected senior Mr. Raj Kumar Ph.D. SRF, Department of Soil Conservation \& Water Management, Chandra Shekhar Azad University of Agriculture \& Technology, Kanpur, (U.P.) India for his keen interest, valuable guidance, and constructive criticism throughout the pursuit of the present research paper and vital suggestion during preparation of this manuscript.

\section{References}

Ali, E.A. and Adel M. Mahmoud (2013). Effect of Foliar Spray by Deferent Salicylic Acid and Zinc Concentrations on Seed Yield and Yield Components of Mung bean in Sandy Soil. Asian Journal of Crop Science 5 (1): 33-40.
Amin Baghizadeh., Mahleghah Ghorbanli., Mohammad Haj., Mahmood Rezaei., Hossein Mozafari (2009). Evaluation of Interaction Effect of Drought Stress with Ascorbate and Salicylic Acid on Some of Physiological and Biochemical Parameters in Okra (Hibiscus esculentus L.) Research Journal of Biological Sciences4 (4): 380-387.

Anonymous (2014). Agricultural statistics at a Glance directorate of Economics and Statistics, Department of Agriculture \& Co-operation, Ministry of Agriculture, Govt. of India, New Delhi.

Fisher, R.A. (1935). The Design of Experiments (8th ed., 1966) New York: Hafner Press.

Muthulakshmi S. and K Lingakumar (2017). Role of salicylic acid (SA) in plants. International Journal of Applied Research. 3(3): 33-37.

Sathiyamurthy, V.A., Saraswathi, T., Tamilselvi, N.A., Sobha Thingalmanian, K., Beaulah, A., Rohini, N. and Arumugam, T. (2017). Effect of Salicylic Acid on Growth, Yield and Storage Quality of Onion (Allium cepa L.) International Journal of Current Microbiology and Applied Sciences ISSN: 2319-7706 Special Issue-4 pp. 78-86.

Shweta Jamra (2017). Effect of foliar application of nutrients on growth and development of black gram (Vigna mungo L.) under rainfed Vertisols of Central India, International Journal of Chemical Studies 6(1): 609-613.

Sujatha, K.B., (2001). Effect of foliar spray of chemicals and bioregulators on growth and yield of green gram (Vigna radiate L.). M.Sc. Thesis, Tamil Nadu Agric. Univ., Coimbatore. India.

\section{How to cite this article:}

Deepak Kumar Rawat, M.A. Khan, Nirmal Kumar, Amit Kumar and Raj Kumar. 2019. Yield Attributes and Yield of Urdbean as Influenced by Foliar Application of Salicylic Acid under Rainfed Condition. Int.J.Curr.Microbiol.App.Sci. 8(08): 1374-1381. doi: https://doi.org/10.20546/ijcmas.2019.808.160 